\title{
Silvicultural contracting in British Columbia
}

\author{
by Sen Wang ${ }^{1}$, G.C. van Kooten ${ }^{2}$ and Bill Wilson ${ }^{1}$
}

Over the past eight decades, British Columbia's silvicultural programs have gone through three stages: initiation, establishment and development. For a long time, silviculture was a minor activity associated with timber harvesting, and the formation of silviculture as a distinct sector did not take place until the late 1960s. Shifts in societal values and changes in public expectations concerning forest management contributed to changes in B.C.'s forestry institutions that, in turn, altered the structure of silviculture programs. Especially since the 1980 s, expansion in the scope and scale of silvicultural activities transformed contractual relationships. This paper profiles the contractual structure of B.C.'s silviculture sector. Results of a survey of contractors indicate that seed orchards, forest nurseries and companies holding timber tenures on public land economize on transaction costs by choosing appropriate organizational and contractual forms in accordance with identifiable attributes of silvicultural activities and firms' characteristics.

Key words: silviculture, contractual forms, transaction cost, payment schemes

\section{Introduction}

Oriented towards reforestation, silvicultural investments in British Columbia began with nursery establishment in the late 1920 s at selected locations on the Coast. Since then, silvicultural activities have evolved primarily in response to changes in the forest resource base, technological advances and shifts in societal values. Several decades of rapid forest development left behind large areas of not-satisfactorily-restocked (NSR) sites that contributed, in the late 1960 s, to the emergence of a distinct silvicultural contracting sector in B.C.

During the past three decades, B.C.'s silvicultural sector faced a number of unique challenges. First, it struggled to expand delivery capacity in response to a dedicated public sector effort through the Canada/B.C. Forest Resource Development Agreement (the FRDA) to regenerate the large area of back$\log$ NSR sites. Almost concurrently, the law was changed so that new cut-over sites had to be restocked (no such requirement existed previously). Second, the sector was born in an era of multiple-use, and it matured as forestry shifted to encompass sustainable development as well as multiple-use. This meant that, in addition to regenerating large NSR areas, silvicultural performance quality was also emphasized, in order to address multiple values. Third, because of predominant public ownership of forest lands and a complex tenure system, silvicultural activities have come to rely, to a great extent,

\footnotetext{
${ }^{1}$ Natural Resources Canada, Canadian Forest Service, 506 West Burnside Road Victoria, B.C., Canada V8Z 1M5.

${ }^{2}$ Forest Economics and Policy Analysis Research Unit, University of British Columbia, Forest Science Centre, 2424 Main Mall, Vancouver, B.C., Canada V6T 124.
}

Au cours des 8 dernières décennies, les programmes de sylviculture de la Colombie-Britannique ont connu trois étapes: l'amorce, la mise en place et l'élaboration. La sylviculture a été pendant de nombreuses années qu'une activité secondaire reliée à la récolte de bois, et la formation de la sylviculture en tant que secteur distinct n'a pas pris place avant la fin des années 60 . Les changements dans les valeurs sociales et les modifications des attentes du public relativement à l'aménagement forestier ont contribué à apporter des changements au sein des institutions forestières de la C.-B. qui, à leur tour, ont modifier la structure des programmes sylvicoles. Tout spécialement depuis les années 80, l'expansion de l'horizon et de l'envergure des activités sylvicoles ont transformé les relations contractuelles. Cet exposé décrit la structure contractuelle du secteur sylvicole de la C.-B. Les résultats d'un sondage sur les entrepreneurs indiquent que les vergers à graine, les pépinières forestières et les allocations de bois des compagnies sur les terres publiques réduisent les coûts de transactions en choisissant des formes organisationnelles et contractuelles appropriées en fonction des attributs identifiables des activités sylvicoles et des caractéristiques des entreprises.

Mots clés: sylviculture, formes contractuelles, coûts des transactions, modes de paiement

on private action under public scrutiny, involving sophisticated institutional arrangements that blend public aspirations with private input. Given the objectives of rapidly restocking NSR land and enhancing the value and productivity of the forest resource base, the expansion in the scope and scale of silvicultural activities led to a policy package that the B.C. government adopted in 1987. As a result, forest companies operating under Crown licenses were given physical and financial responsibility for planting all future cutover sites on public land, according to pre-harvest silvicultural prescriptions, and managing the sites to a free-to-grow stage. A detailed chronology of major institutional and policy changes in B.C.'s silvicultural sector is provided in the Appendix.

The purpose of this paper is to profile the institutional arrangements that have emerged at the operational level - the way silvicultural activities are organized, particularly in terms of contractual relationships and arrangements. The information used in this study is based on separate surveys conducted by the authors in early 1997 of B.C. companies holding timber tenures on public land, nurseries, seed orchards and silvicultural contractors. We begin, however, by outlining the general forms of contractual relationships in B.C.'s silvicultural sector.

\section{Contractual Relationships in B.C.'s Silvicultural Sector}

In British Columbia, silviculture is a relatively small financial and employment component within forestry, although in recent years silviculture has gained greater importance within forestry, partly in response to public sector policy intervention. Because timber harvesting dominates forest management and technology, silviculture's role remains small, making it 
a challenge to identify clearly the interconnectedness between silviculture and the other sub-sectors.

During the past three decades, the main feature of institutional restructuring in B.C.'s silvicultural sector has been the change in contractual relationships. Prior to 1967, when silviculture was confined to nursery work and small-scale tree planting, the B.C. Forest Service (BCFS) hired individuals directly to perform silviculture on Crown land (see Figure 1). After 1967, with an expansion in the scale and scope of silvicultural operations, the handling of an increasing amount of work became more costly. So, instead of directly hiring workers on an individual basis, the government began to assume the role of "principal" with the emergent silvicultural contractors as "agents" (see Brinkman 1992 for background information). The rationale for such arrangements was to minimize transaction costs. Transaction costs include all costs of organizing and managing activities, such as the costs of information gathering, contract negotiation, program enforcement and monitoring. Perhaps silvicultural contractors have lower costs because they possess specialized skills and knowledge, especially at the local level, that would be more difficult for government agencies to acquire and retain. Perhaps contractors can organize individual workers at less cost than the BCFS, thus making it logical for them to serve as a level of management between the workers and BCFS. Assuming contractors are more successful than BCFS in minimizing the problem of moral hazard (the situation where one side of the market cannot observe the actions of the other), transaction costs could be lowered by using silvicultural contractors.

The policy change that took place in 1987 necessitated new delivery arrangements (Figure 1). As a result of the change the existing relationship had to include the major licensees (e.g., holders of Tree Farm Licences (TFLs), Forest Licences and Timber Licences) within a BCFS-major licensees-contractorsworkers model. ${ }^{3}$ The reason for this new relationship had much to do with the rapid growth in the amount and type of silvicultural work and changes in expectations regarding the quality of silvicultural activities. BCFS found it increasingly costly to maintain the old contractual arrangements, so a new "principal-agent" layer was inserted in the silvicultural contracting system that resulted in the further vertical integration of major licensees into silviculture (Figure 1). This change occurred because, from the standpoint of forest management, it provided a foundation for incorporating basic silviculture (defined as the silvicultural practices for achieving free-to-grow regeneration of desired tree species at specified densities and stocking levels) which requires forest regeneration to take place soon after timber harvesting operations. Further, from an administrative and organizational perspective, the policy decentralized silvicultural decisions without altering the fundamental structure of the Province's existing forest tenure system. It effectively anchored the major licensees in the integrated forest management system in a compulsory fashion. The role of BCFS, which became the B.C. Ministry of Forests (MoF) in 1979, included regulatory, administrative and, when necessary, punitive functions. Finally, the new approach improved economic efficiency by economizing on the transaction costs

\footnotetext{
${ }^{3}$ Major licensees had used the services of silvicultural contractors in the $1970 \mathrm{~s}$ for forest regeneration, but most costs were reimbursed by the Forest Service under the stumpage-credit system.
}

$\underline{\text { Pre-1967 }}$

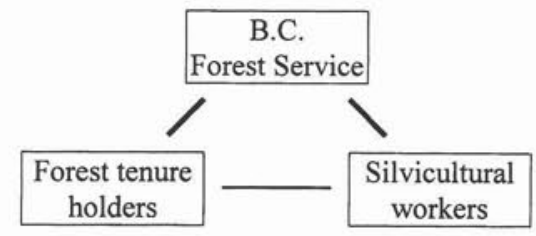

$1967-1987$

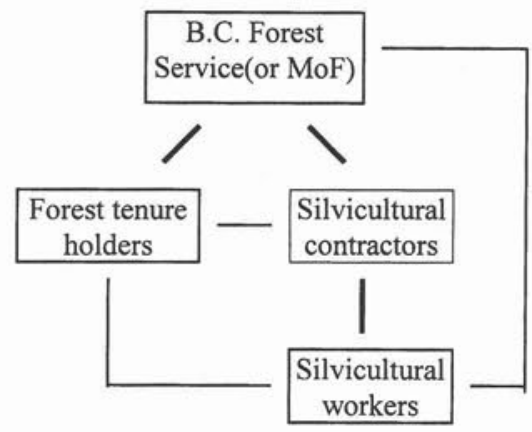

$\underline{\text { Since } 1987}$

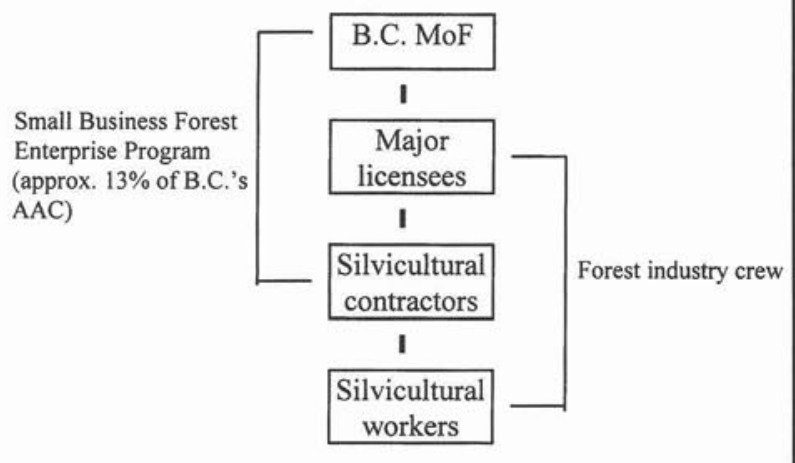

Fig. 1. Evolution in contractual relationship of B.C.'s silviculture sector. Thicker lines indicate major relationships that involve direct contractual relations on a frequent basis whereas thinner lines suggest minor relationships that involve less frequent interactions.

associated with the organization of silvicultural operations. By promoting decentralized contractual relationships, the new approach lowered the costs of contract negotiation, enforcement and information collection.

In essence, the contractual relationships in B.C.'s silvicultural sector are agency relationships. Conceptually, MoF may be viewed as the first-level principal and the major licensees as the second-level principal. ${ }^{4}$ Likewise, the licensee can be described as the first-level agent with the silvicultural contractor the second-level agent. Thus, the principal-agent structure is, more comprehensively, a two-tier relationship with the MoFmajor licensee relationship comprising the first layer and the licensee-contractor relationship forming the second layer. Pursuant to the provisions of the Small Business Forest Enterprise Program (SBFEP), MoF also deals directly with silvi-

${ }^{4}$ Public land ownership remains a basic characteristic, with almost $95 \%$ of the total B.C. area owned by the Crown. 
Table 1. Participation in Silvicultural Activities ( $\%$ of contractors performing activity, $n=52$ )

\begin{tabular}{|c|c|c|c|c|c|c|c|}
\hline Activity & $\begin{array}{c}\text { WSCA } \\
\text { member }\end{array}$ & $\begin{array}{c}\text { Not } \\
\text { WSCA } \\
\text { member }\end{array}$ & $\begin{array}{l}\text { Entire } \\
\text { group }\end{array}$ & $\begin{array}{c}\text { Pre-1987 } \\
\text { contractor }\end{array}$ & $\begin{array}{l}\text { Post-1987 } \\
\text { contractor }\end{array}$ & $\begin{array}{c}\text { Pre-1987 } \\
\text { WSCA } \\
\text { member }\end{array}$ & $\begin{array}{c}\text { Post-1987 } \\
\text { WSCA } \\
\text { member }\end{array}$ \\
\hline Cone collection & 15 & 27 & 21 & 32 & 8 & 18 & 11 \\
\hline Planting & 73 & 35 & 54 & 68 & 38 & 88 & 44 \\
\hline Brushing \& weeding & 77 & 50 & 64 & 68 & 58 & 77 & 78 \\
\hline Pest \& disease control & 15 & 23 & 19 & 21 & 17 & 24 & 0 \\
\hline Spacing & 50 & 50 & 50 & 61 & 38 & 65 & 22 \\
\hline Fertilizing & 15 & 4 & 10 & 14 & 4 & 24 & 0 \\
\hline Surveying & 27 & 58 & 42 & 46 & 38 & 35 & 11 \\
\hline
\end{tabular}

cultural contractors. The SBFEP accounts for some $13 \%$ of B.C.'s annual allowable cut (AAC) and MoF is responsible for silviculture activity on the area harvested under the program (B.C. Ministry of Forests 1996).

At a conceptual level, the principal-agent formulation characterizes the institutional and contractual reforms in B.C.'s silvicultural sector. Yet, it is the second-layer relationship that is essential because silvicultural operations hinge on the major licensee, which acts in a dual role as both a principal and an agent. In consequence, the licensee plays a central role in this new contractual relationship. In the remainder of the paper, we investigate contractual arrangements at the level of silvicultural activities in order to examine "transaction cost minimization" as a rationale for the emergence of B.C.'s silvicultural sector. In particular, we examine which silvicultural activities are conducted in-house and which are contracted out. We do this by considering contractual arrangements for silvicultural activities undertaken by seed orchards, nurseries and forest companies using data from the 1997 surveys. However, we begin with a description of the silvicultural workforce.

\section{B.C.'s Silviculture Contracting Workforce}

Sources differ considerably in regard to the actual number of existing silvicultural contractors in B.C. (Western Silviculture Contractors Association 1997). According to the latest Canadian Silviculture Directory (Canadian Silviculture Magazine 1997), there are 212 contractors in the Province. While the Western Silviculture Contractors Association (WSCA) reports a total of 62 full members and some 20 associate supplier members in early 1997 , it has been estimated that the number of silvicultural contractors is upwards of 500 (Groves 1996). Active contractors are fewer in number. For instance, over the past two years, the MoF Vancouver Forest Region has issued a list that includes some four dozen contractors who have recently held tree planting contracts with MoF.

From MoF, WSCA and other sources (e.g., Council of Forest Industries of B.C.), we compiled a list of 140 contractors to whom questionnaires were mailed. Although B.C.'s silvicultural contracting covers a full spectrum of silvicultural operations, results from 52 responding contractors (response rate $37 \%$ ) reveal at least three features (Table 1). First, B.C.'s silvicultural contractors tend to concentrate on basic silviculture - planting and brushing and weeding. Second, few contractors engage in incremental silviculture (defined as the silvicultural practices in established stands for enhancing stand value and yield). Finally, stewardship contracting, which is end results- based and involves multiple phases and multiple activities, is virtually non-existent.

According to the survey results, the average period that B.C.'s silvicultural contractors have operated is 11 years, with WSCA members averaging 12.4 years and non-members 9.6 years. The silviculture contracting workforce is relatively young: the majority of the contractors surveyed have been in business for less than 15 years, and the two groups that have been around for six to ten years and 11-15 years represent $37 \%$ and $29 \%$, respectively, of all contractors. The overall young age of the contracting force is due to the emergence of a large number of contractors in the past decade or so. Many new contractors are not WSCA members.

Survey results confirm that B.C.'s silvicultural contractors have a noticeable variance in the scope of their activities. From Table 1, the intensity of engagement in silvicultural activities is as follows (in descending order): brushing and weeding, planting, spacing, and surveying. Comparisons between WSCA members and non-members provide no indication that member contractors necessarily involve themselves more fully than non-members in silvicultural work. As shown in Table 1, contractors with more years of experience, regardless of WSCA membership, demonstrate a greater degree of involvement in virtually all activities.

The survey included questions concerning contract length, payment scheme, employment, rate of returned workers and level of management in order to examine the performance.quality of silvicultural activities and management efficiency. Compared with non-members, WSCA members tend to hire more workers and enjoy a higher degree of management efficiency in terms of the percentage of returned workers and ratio of workers to supervisors (Table 2). Many contractors not only adopt piece wages but also payment schemes, such as base wage plus bonus. In comparison, although non-WSCA members also use piece rates, they rely more on hourly wages. One reason for this difference is that, since WSCA members tended to have a longer operational history, they have experience with different sorts of incentive schemes. In this respect, it is possible that new contractors, lacking experience, opt for the hourly wage system for a period in an effort to reduce the risk associated with developing sector knowledge and a steady workforce. Management efficiency is clearly positively related to experience, and this is most noticeable when comparing the survey results for the pre-1987 and post-1987 sub-groups.

In summary, B.C.'s silvicultural contracting has been in existence for some thirty years. The survey shows the following: 


\begin{tabular}{|c|c|c|c|c|c|c|c|}
\hline Category & $\begin{array}{c}\text { WSCA } \\
\text { member }\end{array}$ & $\begin{array}{c}\text { Not } \\
\text { WSCA } \\
\text { member }\end{array}$ & $\begin{array}{l}\text { Entire } \\
\text { group }\end{array}$ & $\begin{array}{c}\text { Pre-1987 } \\
\text { contractor }\end{array}$ & $\begin{array}{l}\text { Post-1987 } \\
\text { contractor }\end{array}$ & $\begin{array}{c}\text { Pre-1987 } \\
\text { WSCA } \\
\text { member }\end{array}$ & $\begin{array}{c}\text { Post-1987 } \\
\text { WSCA } \\
\text { member }\end{array}$ \\
\hline Number of managers & 5 & 3.9 & 4.5 & 5 & 3.8 & 5.3 & 4.4 \\
\hline Workers hired in 1996 & 127 & 49 & 88 & 136 & 32 & 170 & 48 \\
\hline Returned workers (\%) & 66 & 49 & 57 & 61 & 55 & 68 & 63 \\
\hline Worker-manager ratio & 26 & 11 & 19 & 26 & 9 & 36 & 8 \\
\hline \multicolumn{8}{|l|}{ Payment scheme $(\%)^{2}$} \\
\hline - hourly wages & 27 & 77 & 52 & 54 & 50 & 35 & 11 \\
\hline - piece wages & 81 & 54 & 67 & 82 & 50 & 94 & 56 \\
\hline - base wage + bonus & 12 & 15 & 14 & 18 & 8 & 12 & 11 \\
\hline - other (salary, etc.) & 27 & 8 & 17 & 14 & 13 & 24 & 33 \\
\hline \multicolumn{8}{|l|}{ Contract length (days) } \\
\hline - basic silviculture & $66-67$ & $73-88$ & $69-77$ & 67 & 79 & 55 & 94 \\
\hline - incr. Silviculture & $72-77$ & 81 & $76-79$ & 77 & 78 & 61 & 105 \\
\hline Ratio of workers to supervisor & $1-5$ & $1-5$ & $1-5$ & $1-5$ & $1-5$ & $1-5$ & $1-5$ \\
\hline \multirow{5}{*}{ (proportions in brackets) } & $(12 \%)$ & $(46 \%)$ & $(29 \%)$ & $(11 \%)$ & $(46 \%)$ & $(6 \%)$ & $(22 \%)$ \\
\hline & $6-10$ & $6-10$ & $6-10$ & $6-10$ & $6-10$ & $6-10$ & $6-10$ \\
\hline & $(54 \%)$ & $(34 \%)$ & $(44 \%)$ & $(63 \%)$ & $(38 \%)$ & $(59 \%)$ & $(44 \%)$ \\
\hline & $11-15$ & $11-15$ & $11-15$ & $11-15$ & $11-15$ & $11-15$ & $11-15$ \\
\hline & $(35 \%)$ & $(19 \%)$ & $(27 \%)$ & $(26 \%)$ & $(17 \%)$ & $(35 \%)$ & $(33 \%)$ \\
\hline \multicolumn{8}{|l|}{ Preference for ${ }^{3}$} \\
\hline - Forest Service & $15 \%$ & $15 \%$ & $15 \%$ & $18 \%$ & $13 \%$ & $18 \%$ & $11 \%$ \\
\hline - Forest companies & $100 \%$ & $92 \%$ & $96 \%$ & $96 \%$ & $96 \%$ & $100 \%$ & $100 \%$ \\
\hline
\end{tabular}

${ }^{1}$ Weighted average of 52 contracting firms surveyed.

${ }^{2}$ Percentage of contractors using the method.

${ }^{3}$ Percentage of contractors making the indication.

(1) Silvicultural contractors, especially the larger ones who have been in operation for a relatively long period, concentrate their efforts in basic silvicultural activities such as planting and brushing and weeding. (2) Contrary to expectation, contracting experience does not necessarily result in more contract days. (3) There is no evidence indicating that WSCA members win more contracts and/or obtain more secure silvicultural work than nonmembers.

\section{B.C. Ministry of Forests' Silvicultural Contracting}

According to the 1988 amendment to the B.C. Forest Act, $\mathrm{MoF}$ has a mandate to deliver the basic silviculture obligations under the Small Business Forest Enterprise Program, or SBFEP (B.C. Ministry of Forests 1989). Virtually all silvicultural contracts under SBFEP are awarded to independent silvicultural contractors at MoF's Forest District level. In addition to the SBFEP silvicultural contracting, $\mathrm{MoF}$ is involved in the management of Forest Renewal B.C. (FRBC) silvicultural projects. Silviculture specialists with $\mathrm{MoF}$ are responsible for silviculture contracting, site inspection and providing technical advise to practitioners.

According to MoF's Integrated Silviculture Information System (ISIS) database, contracts with MoF for silvicultural activities on Crown land are undertaken by two categories of performers, namely large forest companies and small firms. ${ }^{5}$ Small firms, which comprise independent contractors, are by far the largest group because they carry out over $85 \%$ of MoF silviculture-related contracts. When major licensees have contracts from MoF under the Industry Outstanding category or from FRBC sources, they usually sub-contract the actual work to independent contractors (Raymer 1997).

${ }^{5}$ The MoF's Forest Practices Branch provided the authors with access to the ISIS database.
Except for the contracts executed by MoF's District Offices, the majority of MoF contracts occur in the B.C. Interior - some $83 \%$ of the small firms' contracts are in the Interior, while nearly $80 \%$ of the large companies' contracts are in the Interior.

As far as individual activities are concerned, the most frequently occurring ones are (in decreasing order): surveying, planting, spacing and brushing. These four activities account for $73 \%$ of the total number of MoF silvicultural projects (Table 3). As indicated in Table 4, between 1995 and 1997, there was an increase in brushing and site preparation contracts and a decrease in spacing contracts, but no discernible trend in planting and surveying contracts. The ISIS reporting system was introduced in 1995.

In 1996 the B.C. Forest Renewal Act was amended to require FRBC to establish a forest worker agency which would actively develop a process to match eligible B.C. forest workers with jobs arising through FRBC funded projects and to facilitate priority hiring for eligible B.C. forest workers. ${ }^{6}$ Specifically, the Amendment requires that eligible B.C. forest workers who have experienced or are facing work reductions be given first priority in hiring for FRBC-funded projects. This requirement has led to the creation of an agency, New Forest Opportunities Ltd., which will deliver Coastal silviculture activity funded by FRBC using a union-hiring hall style. $^{7}$

\section{B.C.'s Seed Orchards}

B.C.'s seed orchard program arose from a perception of future timber shortages and a desire to secure a supply of highquality seeds. As a result of an expansion in artificial regen-

\footnotetext{
${ }^{6} \mathrm{BC}$ Forest Renewal Amendment Act.

${ }^{7}$ Existing silviculture contractors are concerned about the impact of this publicly-supported agency on the viability of their businesses and the sustainability of public spending on silviculture.
} 
Table 3. Silvicultural Contracts Funded by MoF, by Performer $(n=2,438)$

\begin{tabular}{|c|c|c|c|c|c|c|c|c|c|}
\hline \multirow[b]{2}{*}{ Activity } & \multicolumn{2}{|c|}{ MoF } & \multicolumn{2}{|c|}{ Large firm } & \multicolumn{2}{|c|}{ Small firm } & \multicolumn{2}{|c|}{ All } & \multirow[b]{2}{*}{ Total } \\
\hline & Coast & Interior & Coast & Interior & Coast & Interior & Coast & Interior & \\
\hline Brushing & & 1 & 17 & 37 & 34 & 249 & 51 & 287 & 338 \\
\hline Direct seeding & & & & & & 1 & & 1 & 1 \\
\hline Fertilizing & & & & & 7 & 4 & 7 & 4 & 11 \\
\hline Five-year plan & & & & 1 & & & & 1 & 1 \\
\hline Juvenile spacing & & 2 & 7 & 21 & 66 & 340 & 73 & 363 & 436 \\
\hline Pest control & & & & 2 & 11 & 8 & 11 & 10 & 21 \\
\hline Planting & 1 & 3 & 8 & 48 & 93 & 327 & 102 & 378 & 480 \\
\hline Pruning & & & & 1 & 29 & 51 & 29 & 52 & 81 \\
\hline Roads & & & & & 1 & 3 & 1 & 3 & 4 \\
\hline Multiple activity & & & & 1 & 2 & 69 & 2 & 70 & 72 \\
\hline Site preparation & 3 & 19 & 2 & 25 & 16 & 207 & 21 & 251 & 272 \\
\hline Stand tending & & & 4 & 9 & 27 & 149 & 31 & 158 & 189 \\
\hline Surveys & 54 & 13 & 19 & 63 & 69 & 314 & 142 & 390 & 532 \\
\hline Total & 58 & 38 & 57 & 208 & 355 & 1722 & 470 & 1968 & 2438 \\
\hline
\end{tabular}

Source: Integrated Silviculture Information System (ISIS), data maintained by the Forest Practices Branch, B.C. Ministry of Forests.

Table 4. Silvicultural Contracts Funded by MoF, by Year $(n=2,438)$

\begin{tabular}{|c|c|c|c|c|c|c|c|c|}
\hline \multirow[b]{2}{*}{ Activity } & \multicolumn{2}{|c|}{1995} & \multicolumn{2}{|c|}{1996} & \multicolumn{2}{|c|}{1997} & \multicolumn{2}{|c|}{ Total } \\
\hline & Contracts & $\%$ & Contracts & $\%$ & Contracts & $\%$ & Contracts & $\%$ \\
\hline Brushing & 12 & 5 & 184 & 14 & 154 & 18 & 350 & 14 \\
\hline Juvenile spacing & 48 & 21 & 257 & 19 & 123 & 15 & 428 & 18 \\
\hline Planting & 36 & 16 & 290 & 22 & 170 & 20 & 416 & 17 \\
\hline Site preparation & 16 & 7 & 164 & 12 & 89 & 11 & 269 & 11 \\
\hline Surveys & 59 & 26 & 282 & 21 & 185 & 22 & 526 & 22 \\
\hline Other & 55 & 24 & 172 & 13 & 130 & 15 & 357 & 15 \\
\hline Total & 226 & 100 & 1349 & 100 & 851 & 100 & 2426 & 100 \\
\hline
\end{tabular}

Source: Integrated Silviculture Information System (ISIS), data maintained by the Forest Practices Branch, B.C. Ministry of Forests.

eration, mainly by planting, an increase in demand for high quality seedlings to reduce timber shortfall generated enthusiasm for developing genetically improved seed (Hanson 1985).

The first seed orchard was established on the B.C. Coast in 1963 at Campbell River. During the 1960s and 1970s, the Forest Service and the forest industry established 25 orchards on the Coast, and, with the exception of one Sitka spruce (Picea sitchensis) orchard and one hemlock (Tsuga heterophylla) orchard, they focused on Douglas-fir (Pseudotsuga menziesii). In 1974, a seed production section was set up in the Reforestation Division of the B.C. Forest Service. It was mandated: (i) to establish first-phase seed production orchards either by grafting of scions or use of seedlings from selected high-quality parent trees to produce regular supplies of seed with high germination vigour and wide adaptability; and (ii) to establish second-phase seed orchards from progeny-tested breeds of proven superior genetic quality. These two objectives were designed to reduce progressively, over the next 20 to 40 years, dependence on chance collection from wild stands (B.C. Forest Service 1974).

To improve coordination of government and industry efforts, two cooperative programs were formed: the Coastal Tree Improvement Council (CTIC), and the Interior Tree Improvement Council (ITIC). The two councils, formed in 1979 and 1981 respectively, have been responsible for making recommendations to the Province's Chief Forester regarding program objectives, strategies, agency involvement, and allocation of workload and research needs for future tree improvements in B.C. For instance, as a result of a CTIC recommendation, ten of the initial Coastal orchards were either abandoned or withdrawn from intensive management because of their environmentally-disadvantaged location. Companies participating in the management of orchards were reimbursed for costs incurred through credits-to-stumpage under section 88 (1) of the Forest Act (1980). ${ }^{8}$ The objectives of the Councils were twofold: (1) to establish programs to increase the levels of genetic gain through testing and breeding, and (2) to produce sufficient orchard seed (incorporating the highest available level of genetic improvement) to meet specific goals established for each species. Meanwhile, private orchards existed to produce seed primarily for private forestlands, and they have been managed and financed without government support.

Orchard planning is based on 37 seed-orchard planning zones. These boundaries represent a compromise between biogeoclimatic zones and subzone boundaries and administrative boundaries. Each planning zone projects long-term seed needs based on planting requirements for each species. The trend for the period between the late 1960s and mid-1980s was to establish and intensively manage seed orchards to produce seed of superior genetic quality for the major species used in reforestation. As of 1992, the total area of seed orchards covered 200 hectares, with MoF managing slightly more than half. Geographically, one third of MoF's orchard area is in the Interior, but $82 \%$ of industry orchards are Coastal (B.C. Ministry of Forests 1992).

\footnotetext{
${ }^{8}$ Adopted in 1980, Section 88 of the Forest Act formalized the credit-to-stumpage practice. It enabled MoF to reimburse timber licensees for approved forestry activities out of required stumpage payments. Silvicultural contractors benefited from Section 88 incidentally because, through this means of financing, timber companies were able to expand forestry activities many of which were undertaken by silvicultural contractors (see Appendix for more details).
} 
We conducted a survey of 16 seed orchards, with 13 responding (response rate of $81 \%$ ). The forest industry's seed orchards are ten years older (mean age 24 years) than MoF orchards (14 years). The average growing area for all seed orchards is 21.1 hectares. The orchards have produced cones, on average, for nine years. In aggregate, cone production ranges from 853 to 1298 hectolitres per annum, for an average of 66 to 100 hectolitres per orchard.

The 13 orchards reported a total of 26 permanent employees, or an average of two per orchard. There are ten professional and administrative staff, or just under one full-time equivalent person per orchard. Some $77 \%$ of seed orchards hire seasonal workers, but none hires more than six (Table 5). Three orchards (23\%), all MoF operated, use their own permanent staff to harvest cones. Workers are universally paid at a time rate. Survey results indicate that $77 \%$ of the orchards use their technical staff for supervising seasonal workers, while the rest (23\%) rely on a combination of technical staff and hired people for supervisory work.

Some $92 \%$ of orchards provide some training, with $69 \%$ of those training their seasonal workers for less than half a day. Longer training (half to a full day) occurs at only $31 \%$ of the seed orchards. No seed orchard provides training in excess of one day.

\section{Profile of B.C.'s Forest Nurseries}

B.C.'s first nursery for production purposes was established at Green Timbers near Vancouver in 1930 (Young 1989a). However, expansion in nursery capacity did not begin until the early 1960s (Young 1989b) because, up to the 1950s, only some of the most highly productive sites in the most accessible areas were considered for restocking (Sloan 1956). For instance, in 1955 approximately seven million seedlings were available for planting in the Province, the majority being planted on the Coast. In 1961, seedling production was still about the same; two years later it had doubled. In 1963, B.C. had three major nurseries, producing 12.5 million trees for planting. With this rate of production and a planting density of 988 trees per ha (400 per acre), only 12650 ha (31 250 acres) could be planted per year. By 1964, 23 million seedlings were produced. The estimated 1965 nursery capacity for seedlings in the Province reached 25 million (Sedlack 1965). At that time, nursery stock production was financed entirely by the government.

Since the late 1960s, planting accelerated, exerting increasing pressure on seedling production capacity. For instance, sowing requests for 1979 totalled 111 million seedlings, 11 million more than the nurseries could grow. The new situation forced the newly created $\mathrm{MoF}$ to explore the possibility of involving private nurseries to meet the increased demand for seedlings (Grant 1979). Quickly, more than one dozen were established. These included commercial operations producing stock for market sale and operations that were both owned and operated by forest companies.

Nursery management represents the greatest concentration of technology and investment in the forest growth cycle and rivals wood processing in capital and labour intensity (Gordon 1984). The nursery production cycle is short relative to many other forestry operations. Since nurseries are the first custodians of seed-orchard seeds, they have received increasing attention from silvicultural managers. Nurseries present a unique opportunity to multiply the effects of technology and
Table 5. Seed Orchard Management in British Columbia, Seasonal Workers $(n=13)$

\begin{tabular}{ccc}
\hline Number of seasonal workers hired per year & $\begin{array}{c}\text { Number of } \\
\text { orchards }\end{array}$ & $\begin{array}{c}\text { Frequency } \\
(\%)\end{array}$ \\
0 & 1 & 8 \\
$1-3$ & 3 & 23 \\
$4-6$ & 4 & 31 \\
$7-10$ & 1 & 8 \\
$>10$ & 3 & 23
\end{tabular}

Period of employment for seasonal workers (Number of weeks)

$\begin{array}{ccc}<5 & 3 & 23 \\ 5-8 & 3 & 23 \\ 9-12 & 1 & 8 \\ >12 & 6 & 46\end{array}$

Percentage of cones harvested by seasonal workers

$$
\begin{gathered}
\leq 25 \\
26-50 \\
51-75
\end{gathered}
$$$$
76-100
$$

$\begin{array}{ll}3 & 2 \\ 1 & 8 \\ 0 & 0 \\ 9 & 69\end{array}$

23

Ratio of seasonal workers to supervisors

$\begin{array}{ccc}<4 & 3 & 23 \\ 4-6 & 5 & 39 \\ 7-10 & 4 & 31 \\ >10 & 1 & 8\end{array}$

research on wood yields (Gordon 1984). After several years of debate and preparation, the government decided to sell nine MoF nurseries. ${ }^{9}$ Located in several different regions, the nurseries included the land, buildings and equipment needed for seedling production, and each was staffed by fully trained and experienced personnel.

Expressions of interest were solicited from the general public, but MoF made it clear at the outset that the government reserved the right to negotiate an agreement directly with affected employees in the event a satisfactory proposal was received from those employees. If no acceptable employee proposals were identified, the normal public bidding process would apply. In any event, the government favoured proposals that emphasized job creation and protection.

In mid-1988, six of the nine nurseries were purchased by an employee group headed by one of MoF's top managers (Vancouver Sun, July 23, 1988, p.B8). The six nurseries involved a total of 100 jobs, with 47 of them being regular full-time jobs. The employees paid \$5 million for the nurseries and they would give the government $\$ 3.9$ million worth of seedlings and service charges over the next five years. The new company signed a four-year contract with $\mathrm{MoF}$ for seedling production and a five-year contract for seedling storage. About the same time, two other nurseries were also privatized. Green Timbers - B.C.'s very first forest nursery - was withdrawn from the privatization process partly in response to public opposition to privatization of the facility (B. Merrel, Superintendent, Green

\footnotetext{
${ }^{9}$ On November 12, 1987, the Vancouver Sun (p.B9) carried an “... invitation to apply for the purchase of 9 B.C. Forest Service nurseries." The nurseries produced 100 million seedlings a year - half the seedlings needed for reforestation by the industry; the other $50 \%$ was supplied privately. The government wanted to retain the other two nurseries (Surrey Nursery and the Skimikin Nursery in Salmon Arm) for research and to provide seedlings for reforestation of lands directly under Ministry control.
} 


\begin{tabular}{|c|c|c|c|c|c|c|c|c|}
\hline Stock type ${ }^{2}$ & 1987 & 1988 & 1989 & 1990 & 1991 & 1992 & 1993 & Total \\
\hline $211 \mathrm{~A}$ & 36518 & 62072 & 59158 & 38639 & 26807 & 15552 & 11969 & 250715 \\
\hline $310 \mathrm{~A}$ & & & & & & 101 & 29 & 130 \\
\hline $310 \mathrm{~B}$ & & & & & 1413 & 1428 & 805 & 3646 \\
\hline 312 & & & & & & & 254 & 254 \\
\hline $313 A$ & 70128 & 74226 & 92515 & 51892 & 31791 & 23615 & 7815 & 351982 \\
\hline 313B & 43399 & 57289 & 72251 & 76772 & 66409 & 63954 & 62600 & 442674 \\
\hline $313 \mathrm{C}$ & & & & & 2 & 645 & 815 & 1462 \\
\hline 313D & & & & & 2 & 296 & 201 & 499 \\
\hline 315 & & & & & & 2 & & 2 \\
\hline $323 \mathrm{~A}$ & & & 8 & 20 & 3 & 5 & & 36 \\
\hline 410 & & & & & 1516 & 5392 & 11861 & 18769 \\
\hline $415 \mathrm{~A}$ & & & & 1789 & 222 & 129 & 17 & 2166 \\
\hline 415B & 8509 & 18787 & 35575 & 45933 & 40473 & 62862 & 52551 & 264690 \\
\hline $415 \mathrm{C}$ & & & & 850 & 376 & 686 & 497 & 2409 \\
\hline 415D & & & & 2439 & 2945 & 5225 & 8810 & 19419 \\
\hline $515 \mathrm{~A}$ & & & & & & & 20 & 20 \\
\hline $615 \mathrm{~A}$ & 27 & 92 & 347 & 265 & 406 & 445 & 561 & 2143 \\
\hline $615 B$ & & & & & & 20 & 81 & 101 \\
\hline Other ${ }^{3}$ & 32480 & 28051 & 38866 & 23065 & 20172 & 14935 & 13820 & 171389 \\
\hline Total & 191061 & 240517 & 298742 & 249917 & 210520 & 233871 & 224789 & 1649417 \\
\hline
\end{tabular}

${ }^{1}$ Compiled from Scagel et al. 1993.

${ }^{2}$ Stock type listed here are plug styroblock container seedlings.

${ }^{3}$ Other stock types include bareroot, plug transplanted bareroot, container rooted cutting, plug copper treated, and container paper pot.

Timbers Forest Nursery, Surrey, B.C., personal communication, 1997).

Prior to October $1987, \mathrm{MoF}$ was financially responsible for growing almost all of the seedlings planted on Crown land. As a consequence of the changes in responsibility for funding reforestation in the province, the administration of contracts, seedling morphological and physiological quality, nursery culture, pest management, shipping and cold storage became important to all licensees and nurseries due to changes in the supplier-customer relationship. Among other things, Bill 70 or the Forest Amendment Act (1987) created a forest industryfunded seedling market (Brazier 1991).

Since the early 1980 s, production of forest planting stock in containers in B.C. has increased rapidly. Currently, of the some 220 million seedlings raised each year, over $90 \%$ are container-grown. The principal species are spruces (Picea engelmannii, Picea glauca and Picea sitchensis), lodgepole pine (Pinus contorta), Douglas-fir (Pseudotsuga menziesii), western red cedar (Thuja plicata), hemlock species (Tsuga heterophylla and Tsuga mertensiana), true firs (Abies amabilis) and miscellaneous other species, including Ponderosa pine (Pinus ponderosa), western larch (Larix occidentalis) and yellow cedar (Chamaecyparis nootkatensis).

The change in 1987 from a single government buyer to a multiplicity of purchasers has resulted in a market-driven forest seedling industry. Market demands have increased the number of stock types from 8 in 1986 (Brazier 1991) to 35 in 1993 (Scagel et al. 1993). In terms of stock types sown, 1+0 containers have increased to dominate the market, $2+0$ containers declined somewhat, bare-root seedlings continue to decline, and transplants increased during the late 1980s and early 1990 s. ${ }^{10}$ There has been a general trend from small containers to larger ones (Table 6).

\footnotetext{
${ }^{10}$ Plug styroblock (PSB) is a commonly used container stock type. For a given species, a stock type name is comprised of nursery culture and growing seasons. For instance, $1+0$ means one-year-old seedling, i.e., one year in container and 0 year in transplanting stage.
}

In summary, B.C.'s nursery capacity presently exceeds demand. Three trends have been visible over the past 10 to 15 years: container seedlings have replaced bare-root seedlings; larger stock types have increased proportionally; and nursery production has shifted to greenhouses. These changes and Bill 70 created new facilities to meet the customer requirements of an increased number of clients (Brazier 1991).

We conducted a survey of 43 forest nurseries in B.C. and received 34 responses (response rate $79 \%$ ). Of the 34 nurseries, four are $\mathrm{MoF}$ nurseries, six are major forest companies nurseries, and the remaining 24 are commercial ones (Table 7). ${ }^{11}$ The MoF nursery at Cowichan Lake Research Station is not included in our statistical calculations due to its focus on research. The MoF and commercial nurseries are larger in both area and production than nurseries operated by forest companies. Only half a dozen forest companies have their own nurseries because the planting programs of many firms are too small to support an independent tree nursery. Nurseries have been in operation for an average of 14 to 17 years, which corresponds with the time when $\mathrm{MoF}$ decided to encourage private efforts in seedling production.

The three MoF production nurseries currently produce 25 million seedlings, but, since MoF needs to make 45 million seedlings available for planting, some 20 million seedlings are contracted out to private growers. The selection of private nurseries is done on a rating basis handled by a nursery contract review board. The formula is a weighted average of $60 \%$ quality of seedlings and $40 \%$ ability and contract price (B. Merrel, Superintendent, Green Timbers Forest Nursery, Surrey, B.C., personal communication, 1997).

MoF nurseries have the largest permanent staff and technical personnel and do not hire seasonal workers to the same

\footnotetext{
${ }^{11}$ B.C. MoF identified two categories of private nurseries. Private tree seedling nurseries under contract to the Ministry, for direct payment of seedlings destined for Crown land, are categorized as commercial nurseries. Private nurseries operated by forest companies that harvest on Crown land are called industry nurseries.
} 
Table 7. Forest Nurseries in British Columbia, by Category $(n=34)$

\begin{tabular}{lccccc}
\hline $\begin{array}{l}\text { Nursery } \\
\text { category }\end{array}$ & Number & $\begin{array}{c}\text { Average years } \\
\text { in operation }\end{array}$ & $\begin{array}{c}\text { Average } \\
\text { size (ha) }\end{array}$ & $\begin{array}{c}\text { Total capacity } \\
\text { (million) }\end{array}$ & $\begin{array}{c}\text { Mean annual } \\
\text { capacity (million) }\end{array}$ \\
\hline MoF & 4 & 36 & 340 & 36 & 12 \\
Industry & 6 & 15 & 14.6 & 29 & 4.8 \\
Commercial & 24 & 14 & 30.1 & 240 & 10 \\
Overall & 34 & 17 & 64 & 305 & 9 \\
\hline
\end{tabular}

Table 8. Forest Nursery Management in British Columbia $(n=34)$

\begin{tabular}{lccccc}
\hline \multirow{2}{*}{$\begin{array}{l}\text { Nursery } \\
\text { category }\end{array}$} & $\begin{array}{c}\text { Permanent } \\
\text { employees }\end{array}$ & $\begin{array}{c}\text { Technical } \\
\text { staff }\end{array}$ & \multicolumn{3}{c}{ Intensity of seasonal hiring (\%) } \\
\cline { 4 - 6 } MoF & 10 & 9.3 & 33 & $\mathbf{1 1 - 2 0}$ & 33 \\
Industry & 6 & 2.4 & 17 & 33 & 67 \\
Commercial & 9 & 4.7 & 8 & 25 & 67 \\
Overall & 8 & 4.7 & 12 & 24 & 64 \\
\hline
\end{tabular}

extent as private nurseries (Table 8). Regardless of nursery category, temporary workers are invariably hired for laborintensive jobs such as thinning, weeding, lifting and packing. MoF nurseries tend to contract out activities such as lifting, maintenance, and so on. Several industry nurseries also contract out some activities, but the commercial nurseries do not contract out at all.

Normally, the period of employment for seasonal workers is around 3 to 6 months. With a few exceptions, seasonal workers are from local communities. Some exceptions occur with the forest industry nurseries. As far as unionization is concerned, MoF nurseries are $100 \%$ unionized and forest industry nurseries are largely unionized. Of the commercial nurseries, unionization is generally not a factor except for a few relatively large nurseries. Time rate is the predominant payment method for seasonal workers. However, some one third of the nurseries have also adopted a piece-rate system, or production bonus schemes.

We found that, due to their relatively greater permanent and technical staff component, the MoF nurseries can afford to let one person supervise fewer seasonal workers; the ratio of supervisor to workers is considerably lower in both commercial and forest industry nurseries (Table 9). As far as training is concerned, up to $90 \%$ of the nurseries provide some form of training to seasonal workers. Although training typically lasts half a day at the beginning of every employment season, private nurseries tend to spend a little longer on training than the MoF nurseries, perhaps because MoF nurseries employ a higher ratio of supervisors to workers.

\section{Silvicultural Contracting by the Forest \\ Industry}

Given the nature of institutional reforms in the B.C. silvicultural sector, major forest licensees are a key component of silvicultural decision-making and delivery. A list of forest companies was developed using the MoF annual reports and information from the Council of Forest Industries of British Columbia (COFI) and the affiliated industry associations. In total 117 questionnaires were sent out to companies or major divisions of companies, and the response rate was $88 \%$ (or 103 completed surveys). About two-fifths of the companies (or their divisions) operate on the Coast.

Survey results indicate that $44 \%$ of the major licensees have separate silvicultural divisions, some divisions appearing in

\begin{tabular}{|c|c|c|c|c|c|}
\hline \multirow[b]{2}{*}{$\begin{array}{l}\text { Nursery } \\
\text { category }\end{array}$} & \multicolumn{2}{|c|}{ Responsibility (\%) } & \multicolumn{3}{|c|}{$\begin{array}{c}\text { Number of seasonal workers } \\
\text { being supervised (\%) }\end{array}$} \\
\hline & $\begin{array}{l}\text { Technical } \\
\text { staff }\end{array}$ & $\begin{array}{c}\text { Tech. + hired } \\
\text { people }\end{array}$ & $<10$ & $11-20$ & $>20$ \\
\hline $\mathrm{MoF}$ & 33 & 67 & 67 & 0 & 33 \\
\hline Industry & 83 & 17 & 17 & 33 & 50 \\
\hline Commercial & 75 & 25 & 21 & 63 & 17 \\
\hline Overall & 73 & 27 & 24 & 52 & 24 \\
\hline
\end{tabular}

the 1950s. However, most firms did not establish separate silvicultural divisions until the 1980s or 1990s. All major forest companies now have separate silvicultural divisions.

Only $45 \%$ of the respondents operate with an AAC exceeding $500000 \mathrm{~m}^{3}$, while $59 \%$ indicated that they have some form of area-based tenure, such as TFL or private land. However, a considerable number of licensees $(41 \%)$ do not have any areabased tenures, having only volume-based Forest Licences. Economic theory and empirical research support suggest that area-based tenure does not generate adequate incentives for direct silvicultural expenditures (Luckert and Haley 1993, Zhang 1996).

The majority of licensees have few permanent silvicultural staff. The survey results indicate that only $14 \%$ of the licensees have more than ten permanent silvicultural staff, while companies with more than two registered professional foresters (RPFs) or administrative staff account for a mere $30 \%$ of all firms. It would seem that silviculture is not a high priority or that silvicultural activities are largely contracted out.

Forest companies generally do not directly hire a large number of seasonal workers, with only $37 \%$ of licensees hiring ten seasonal workers or more each year. For those companies that do hire seasonal workers, the work period is relatively short. Only $46 \%$ of the respondents provide longer than three months of silvicultural work, with many forest companies in the Province providing less than three months of silvicultural work. Only one third of the respondents report that they have basic silvicultural contracts longer than three months. Some $65 \%$ of the major licensees surveyed reported that incremental silviculture work was available at their operations. Monitoring of individual performance is done either by managers of a firm or by hired checkers and evaluators. Silvicultural workers are paid an hourly rate $(41 \%)$, a piece rate $(25 \%)$, or a salary $(34 \%)$. 
Table 10. Ranking of Determinants for Silviculture Contractor Selection $(n=103)$

\begin{tabular}{lc}
\hline Determinants & Percentage indicating \\
\hline Successful relationship in the past & 91.3 \\
Good reputation & 77.7 \\
Employment for local community & 61.2 \\
Low bid & 52.4 \\
Union issue & 4.9 \\
\hline
\end{tabular}

Up to $93 \%$ of the respondents indicated that they had a "preferred contractor," with only $35 \%$ indicating that they relied on "low bid." Yet, silvicultural contracting appears to be quite competitive. Nearly $80 \%$ of respondents reported that four to seven contractors were available to them, whereas $17 \%$ of the companies indicated that there were less than three contractors available in their region; two companies even reported that they each had more than seven contractors to choose from.

The survey results also suggest that there is some mobility among silvicultural contractors. One third of the companies hired less than $30 \%$ of their contractors from the local community, and another one third relied on between $30 \%$ and $70 \%$ of contractors from the local community.

As a result of in-person interviews prior to mailing out questionnaires, five determinants for selecting contractors were identified - low bid, good reputation, successful relationship in the past, whether the contractor was unionized, and employment for the local community (Table 10). It turns out that companies put a great deal of weight on previous experience and reputation as main criteria for selecting contractors.

When asked to rank contract negotiation on a five-point scale ( $1=$ low, $5=$ high), the majority of the respondents rated it as moderately complex. An escape clause that allows contracting parties to terminate an agreement or re-negotiate is usu-
Table 11. Silvicultural Performance in B.C., by Contractual Form (\%) $(n=103)$

\begin{tabular}{lccc}
\hline Activity & In-house & Contracting out & Both \\
\hline Cone collection & 14 & 77 & 8 \\
Seedling production & 9 & 78 & 13 \\
Site preparation & 23 & 53 & 24 \\
Planting & 13 & 62 & 24 \\
Brushing and weeding & 6 & 78 & 16 \\
Spacing & 9 & 81 & 11 \\
Pruning & 7 & 88 & 5 \\
Thinning & 7 & 88 & 5 \\
Fertilizing & 9 & 85 & 6 \\
Surveying & 36 & 25 & 39 \\
\hline
\end{tabular}

ally included in silvicultural contracts. Re-negotiation (usually on an annual basis) is quite common, with $60 \%$ of companies having re-negotiation provisions in their contracts. Forty percent of the companies choose to negotiate with their partners on an ad hoc basis; (re-)negotiation of contract terms takes place upon a request from one of the parties. Negotiation is the predominant form $(96 \%)$ of dispute resolution, followed by arbitration (7\%) and litigation (3\%). The latter two ways of handling disputes are only reported by several large coastal companies.

Silvicultural activities are either contracted out or performed in-house within the corporate structure. Some firms adopt both forms at the same time. Table 11 provides a summary of internal and contract-out frequencies by various silvicultural activities. Surveying and site preparation are the most likely activities to be internally delivered.

\section{Concluding Remarks}

Survey results from B.C.'s silviculture contracting industry suggest three general conclusions. First, a network of contractual

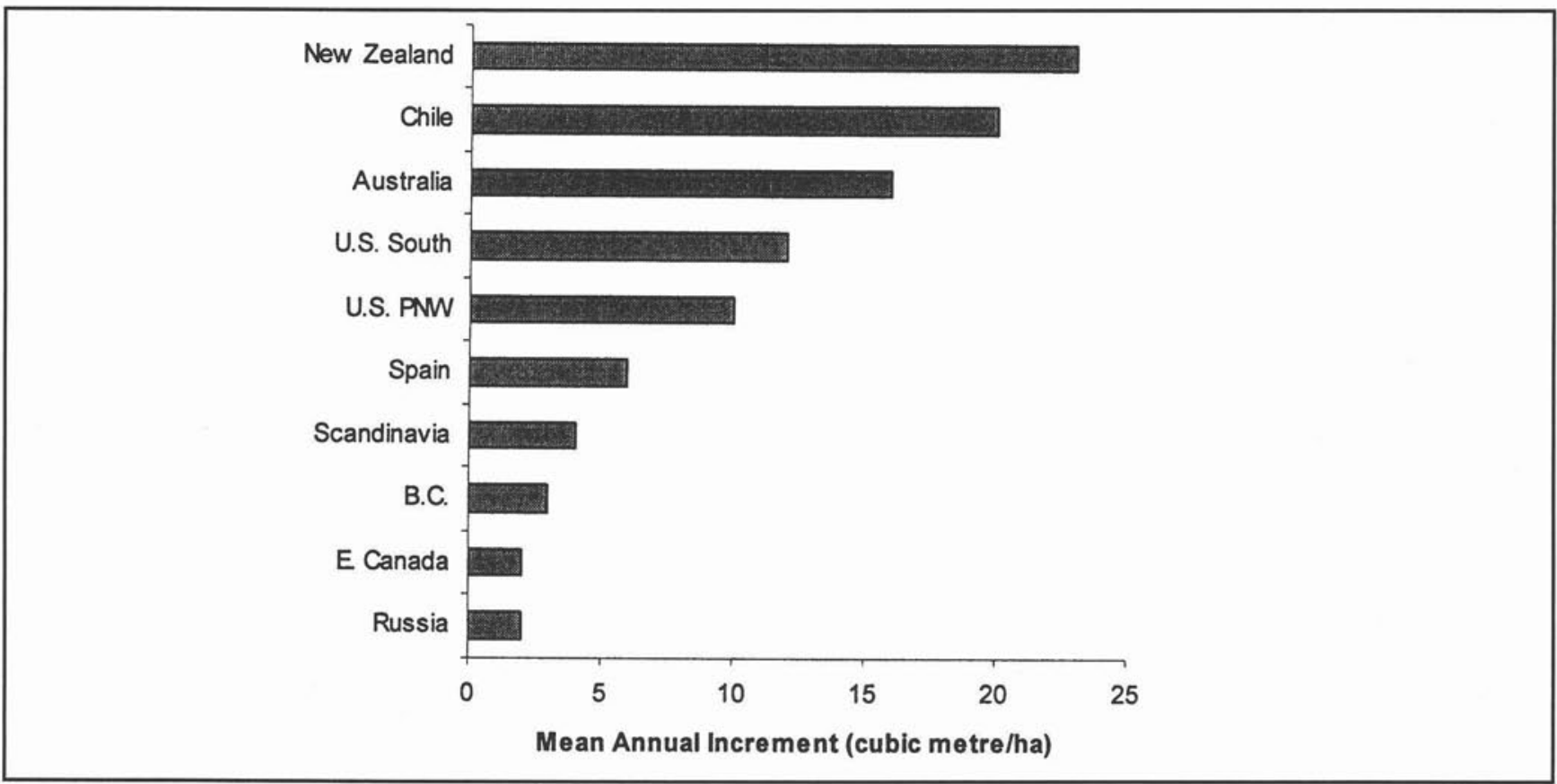

Fig. 2. An International Comparison of Timber Growth Rates. Source: Wilson and Arthur. 1998. New Zealand. In Wilson et al. (eds.). Forest Policy: International Case Studies. CAB International, Oxford, UK. 
relationships exists in the B.C. silvicultural sector. Largely vertical in nature, this relationship reflects the "MoF-Major Licensee-Independent Contractor" hierarchy that characterizes B.C.'s silviculture institutional matrix. Second, firms, whether a seed orchard, a nursery or a forest company, choose appropriate contractual arrangements for various silvicultural activities that reduce transaction costs. Thus, firms contract out straightforward and labour-intensive activities, while opting for in-house delivery of those operations that require a high level of technical skill and the use of specialized equipment. Third, with the exception of the recent intervention under the ambit of FRBC, silviculture expenditures in B.C. remain largely aimed at site preparation, planting, brushing and other basic silviculture activities. FRBC, drawing upon public revenue raised via stumpage on Crown timber, has provided considerable funding for incremental silviculture. ${ }^{12}$ There is little private sector expenditure on incremental silviculture. Growing timber is inherently capital intensive and will increasingly challenge commercial forestry in transition from extensive management on a natural timber endowment to intensive management on a plantation basis.

The survey results suggest that government funds incremental silvicultural activities. The need for public funding is characteristic of many jurisdictions, including some of those in the southern hemisphere with relatively high mean annual growth rates that produce merchantable timber in less than thirty years. For example, New Zealand allows immediate tax write-off of silviculture expenditures against income from other sources and Chile has relied heavily on direct government silviculture subsidies pursuant to Decree Law 701 (Wilson et al. 1998). As indicated in Figure 2, both of these jurisdictions enjoy a considerable advantage in mean annual increment (or timber growth rates) in comparison to traditional commercial forestry regions such as B.C., the US Pacific Northwest and Scandinavia.

Public sector intervention in incremental silviculture must proceed with caution for three reasons. First, from an economic efficiency perspective, the long rotation lengths (around 60 years on the B.C. Coast and up to 100 years in the B.C. Interior) make it financially unattractive given the high levels of costs in initial establishment and subsequent management (Wilson et al. 1998, Brumelle et al. 1991, Benson 1988). The costs of producing incremental gains in fibre production tend to outstrip potential future gains accruing from distant harvests. Second, undertaking incremental silviculture requires the establishment and maintenance of permanent silvicultural crews that need to operate on a year-round basis. However, having workers space, prune and fertilize stands for up to nine months a year poses a financial challenge for the industry because of the long rotation periods and lack of opportunities for generating interim cash flows from timber assets. ${ }^{13}$ Finally, public funding in incremental silviculture has an opportunity cost, which must be prop-

\footnotetext{
${ }^{12}$ The scale of the public entry will affect the structure and financial operating environment in silvicultural contracting. Given the competing demands on public resources, the sustainability of public sector direct spending on silviculture will be under pressure.

${ }^{13}$ Shorter rotations and commercial thinning have provided financial incentives in other forestry jurisdictions to invest in intensive forestry. In many cases these jurisdictions are successfully attracting significant private sector investment both from within the forest sector and increasingly from institutional investors and managed investment funds.
}

erly evaluated in light of other alternatives available in forestry and elsewhere in an economy. Existing international experience provides little support for massive public intervention in silviculture, and that which has occurred, such as in New Zealand in the 1920s and 1930s, was undertaken for largely social and political rather than forest economics.

Forestry has been and remains a critical component of the B.C. economy and it is important that careful deliberation be given to providing an institutional setting that encourages sustainable management of the forest resource. This must include the ability to finance investment in growing the next generation of timber.

\section{References}

Benson, C.A. 1988. A need for extensive forest management. For. Chron. 64: 421-430.

Brazier, D. 1991. A review of changes in B.C. forest seedling market during the period $1986-1991$. In F.P. Donnelly and H.W. Lussenburg (compilers). Proceedings of the 1991 Forest Nursery Association of British Columbia Meeting. pp.37-42. The Forest Nursery Association of British Columbia.

Brinkman, D. 1992. The silviculture contracting game in Canada. In Stewardship in the New Forest - Proceedings of the Silviculture Conference, November 1991, Vancouver, B.C. pp.167-176. Forestry Canada, Ottawa.

British Columbia Forest Service. 1974. Annual Report. Victoria, B.C.

British Columbia Ministry of Forests. 1989. Five Year Forest and Range Resource Program 1989-1994. Victoria, B.C.

British Columbia Ministry of Forests. 1992. Ministry of Forests Fact Sheet on Seed Orchards. Victoria, B.C.

British Columbia Ministry of Forests. 1996. Five-Year Forest and Range Resource Program 1996-2001. Victoria, B.C.

British Columbia Ministry of Forests. 1997. Forest Jobs for B.C.-News Release of Jobs \& Timber Accord. Victoria, B.C.

Brumelle, S.L., J.S. Carey, I.B. Vertinsky and D.A. Wehrung. 1991. Evaluating silvicultural investments: a review in the Canadian context. Forest Product Abstracts 14 (5): 217-270.

Canadian Silviculture Magazine. 1997. 1997 Canadian Silviculture Directory. Vol. 5 , No. 1.

Gordon, J.C. 1984. Nurseries in the Northwest: a unique opportunity for improving forest yield. In M.L. Duryea and T.D. Landis (eds.). Forest Nursery Manual: Production of Bareroot Seedlings. pp.315-317. Martinus Nijhoff/Dr W. Junk Publishers, The Hague/Boston/Lancaster. Grant, P. 1979. One hundred million and still growing. ForesTalk 3(2): 13-19.

Groves, J. 1996. B.C. green and their pockets full of greenbacks: tree planting - a growth industry. The Vancouver Courier, Vol. 87, No. 37, May 8.

Hanson, P. 1985. Seed Orchards of British Columbia. B.C. Ministry of Forests. Victoria, B.C.

Luckert, M.K. and D. Haley. 1993. Canadian forest tenures and the silvicultural investment behaviour of rational firms. Can. J. For. Res. 23: $1060-1064$.

Raymer, B. 1997. Contract Administrator, Forest Practices Branch, B.C. Ministry of Forests. Victoria, B.C. Personal communication. Scagel, R., R. Bowden, M. Madill and C. Kooistra. 1993. Provincial Seedling Stock Type Selection and Ordering Guidelines. Ministry of Forests, Victoria, B.C.

Sedlack, J.P. 1965. The Improvement of Forest Nurseries through the Introduction of Better Soil. Unpublished BSF thesis. Faculty of Forestry, University of British Columbia, Vancouver, B.C.

Sloan, G.M. 1956. The Forest Resources of British Columbia. Queen's Printer, Victoria, B.C.

Western Silviculture Contractors Association. 1997. Profile of Core Silviculture Contracting Activities in British Columbia. Report pre- 
pared by Coopers \& Lybrand Consulting. Vancouver, B.C. Wilson, B., G.C. van Kooten, I.B. Vertinsky and L. Arthur. 1998. Forest Policy: International Case Studies. CAB International Ltd., Oxford, UK.

Young, B. 1989a. The Green Timbers Plantations: a British Columbia forest heritage. For. Chron. 65: 183-184.

Young, B. 1989b. The history of British Columbia's forest nursery sector. In Proceedings of the 1989 Forestry Nursery Association of British Columbia Meeting. p.8. The Forest Nursery Association of British Columbia.

Zhang, D. 1996. Forest tenures and land value in British Columbia. J. For. Econ. 2: 7-30.

\section{Appendix}

\section{Chronology of Major Events and Policies Regarding}

B.C.'s Silviculture

1912 Passage of B.C.'s first Forest Act; creation of the Forest Branch.

1923 Amendments to the Forest Act, introducing seed tree regulations.

1925 Establishment of Forest Reserve Account to provide fund for planting.

1927 Initiation of experimental harvesting in favour of reforestation.

1930 Establishment of B.C.'s first production nursery at Green Timbers in Surrey.

1932 Planting of logged-over land on West Thurlow Island.

1936 Beginning of operational planting by the Forest Branch.

1937 Mulholland's appeal for more efforts in reforestation.

1938 Huge forest fire at Campbell River, destroying 31000 hectares of forests; in response, the Forest Branch accelerated reforestation program by planting 4050 hectares each year and this policy marked the beginning of production planting in B.C.

1938 Tree planting initiated by predecessor companies of MacMillan Bloedel.

1945 Release of first Sloan Royal Commission report.

1946 Establishment of Silviculture Fund.

1947 Expansion of nursery capacity on the Coast and first production from the Duncan nursery.

1950 Supply by government of free seedlings for replanting of denuded privately owned forest land.

1953 Denuded private forest land subject to Forest Service examination and planting of NSR private forest lands becoming mandatory.

1956 Release of second second Sloan Royal Commission report, urging artificial regeneration in the Interior; building of a seed extraction plant at Duncan; initiation of seed registration program.

1958 Organization of the Plus Tree Board; commencement of genetically improved seed production; pilot plantations in the Interior; establishment of small nurseries at Ranger Stations in the central Interior.

1964 Forest Act amended to permit payment as compensation for post-logging silvicultural treatments by stumpage offset or by funds appropriated by the Legislature.

1967 First production of seedlings from a nursery at Red Rock, close to Prince George; swelling of planting program beyond the Forest Service in-service capacity, and planting contracts being advertised for competitive bidding, marking the beginning of the separation of silviculture as a distinct industry from the forest industry in B.C.

1971 Interior exceeded Coast in artificial regeneration for the first time in B.C.'s history.

1972 Forest Act amendment, urging all tenure holders to be responsible for post-logging reforestation.

1975 Initiation of the biogeoclimatic ecosystem classification project, which was not completed until 1994, and this system has provided the foundation for silvicultural decision making.

1976 Release of Pearse Royal Commission report.

1978 Passage of a new Forest Act, Ministry of Forests Act, and Range Act, the above three Acts providing a new framework for the management, protection and conservation of B.C. forest and range resources, replacing the Forest Act of 1912 and the Grazing Act of 1919. Timber Sale Harvesting Licence replaced by newly created Forest Licence; FL together with TFL and Timber Licence holders being required to submit a management and working plan with explicit regeneration commitment.

1979 Intensive Forest Management Subsidiary Agreement was signed between federal and provincial governments as a cooperative support to silviculture. It was expected to terminate on March 31, 1984, but was extended for one additional year and expired on March 31, 1985.

1980 Credit to Stumpage Regulation, under Forest Act (Section 88), B.C. Regulation 433/80, Order in Council 2132, was approved and ordered. Section 88 of the Forest Act became the principal means of financing forest management activities undertaken by licence holders. It allowed the Ministry to reimberse licensees for approved activities, such as planting, by deducting the cost of activities from the stumpage the licensee would otherwise pay to the government.

1980/81 White Paper on the Growing of Tree Seedlings, a significant policy decision concerning nurseries in that: (i) production from Ministry nurseries will be constrained to about 100 million seedlings per year; (ii) all production above this level required to meet the five-year program goals will be achieved through the development and expansion of private nurseries, and (iii) the Ministry will pay for the cost of producing seedlings in private nurseries that are used to restock Crown land. As a result of this policy, in 1980-81 the Ministry approved four nurseries to be developed by the forest industry (licensees), and 7 commercial nurseries were allocated production.

1981/82 Duncan Seed Centre facility became inadequate to meet future program needs, so planning for a new facility began during the year.

1983/84 Shifting of more forest management responsibilities to holders of Tree Farm Licences was proposed in a discussion paper.

1984-85 To improve cost-effectiveness, a large $2+0$ container seedling program was initiated since some sites required larger planting stock, which could compete successfully with other vegetaion. 
Seedlings of this type were intended to replace more costly transplanted seedlings on brushy sites.

The Five-Year Forest and Range Resource Program, 1985-1990 proposed substantial increase of planting to reach 200 million seedlings per year.

Provincial and federal governments signed the first Canada-British Columbia Forest Resource Development Agreement (FRDA I), \$300 million, which emphasized the regeneration of 738000 hectares of good and medium sites of accessible forest land denuded prior to 1982.

1986 The Forest Stand Management Fund was established to fund silviculture and related activities to enhance the provincial forest resource. Matching contributions to this fund were anticipated from the federal government, forest industry, municipalities and forest sector trade unions.

A new seed centre was established at Surrey, replacing the one at Duncan.

A Memorandum of Understanding between Ministry of Forests and Lands and Ministry of Health on Minimum Standards for Silviculture Camps was reached.

Canada signed with USA a softwood Memorandum of Understanding (MOU) in which the Canadian government proposed to lift the US $15 \%$ duty and establish a $15 \%$ export tax on all softwood lumber exports to the U.S. It was agreed that this tax could be eliminated if provincial governments took "replacement measures" to raise stumpage fees to the equivalent level of the export tax.

1987 B.C. government announced major policy changes via amendments to Forest Act, i.e., Bill 70:

- cost and responsibility for basic silviculture up to a free-to-grow tree crop was shifted to the industry (on Timber Sale Licences the Crown continues to carry out the silviculture work with funding from the Small Business Forest Enterprise Account);

- a new pricing system, namely, the comparative value stumpage pricing system, was introduced, and an increase in stumpage was implemented;

- the TFL program was proposed to expand from $28 \%$ to about $66 \%$ of the provincial AAC to provide industry with more tenure security;

$-5 \%$ of major licensees' timber harvesting rights were reallocated under the SBFEP.

Pre-Harvest Silviculture Prescription was implemented and major licensees were obliged to prepare PHSPs for approval prior to harvesting.

1988 Small Business Forest Enterprise Program and its Account were established.

Introduction of a silviculture regulation, which outlined the contents for a PHSP and the requirements to meet basic silviculture obligations.

Privatization of eight government nurseries, with the Crown retaining three only.

1990 Initiation of the Silvicultural System Program to investigate alternatives to conventional clearcutting and to identify their ecological, operational and socio-economic implications and opportunities.
FRDA II was signed - \$200 million for four years, covering the fiscal period 1991-92 to 1994-95. The primary objectives of the agreement were to conduct incremental silviculture (spacing, pruning, fertilization) and to fund initiatives in communications, extension, research, small-scale forestry, product and market development and economic and social analysis.

1991 Release of Forest Resources Commission's report The Future of Our Forests that contains recommendations on silviculture and many other forest related aspects.

1992 Establishment of Commission on Resources and Environment (CORE).

National Forest Strategy and Canada Forest Accord, the provincial, territorial and federal governments, as well as industry, labour, First Nations and environmental groups signed the Canada Forest Accord, committing to the concept of sustainable forestry.

Announcement by the B.C. government of a Protected Areas Strategy, the goal being to achieve $12 \%$ of the province under protection by the year 2000 .

1994 Passage of three pieces of legislation:

- Forest Renewal Act;

- Forest Practices Code of British Columbia Act;

- Forest Land Reserves Act.

Silviculture Regulation replaced by the Silviculture Practices Regulation, which established requirements for administrative penalties, improved soil conservation and maximum densities for all conifer species.

Forest Renewal B.C. Plan was announced in April 1994. Forest Renewal B.C., a new Crown agency, was established in the same year by the B.C. Forest Renewal Act. Forest Renewal B.C.'s funding is derived from increases in stumpage and royalties paid by companies to harvest timber on Crown land. On May 1, 1994, stumpage rates were increased to begin generating this revenue.

1995 The Forest Practices Code Act came into effect.

1996 B.C. Forest Renewal Act amended to assign priority hiring to displaced forest workers on all FRBCfunded projects.

1997 On June 19, Premier Glen Clark announced the Jobs and Timber Accord, aimed at creating 39800 new jobs by $2001 ; 5000$ of these jobs are expected to come from forest renewals (B.C. Ministry of Forests 1997).

New Forest Opportunities Ltd. is established pursuant to B.C. Forest Renewal Amendment to deliver government silviculture activity in Coastal region. 